\title{
HPLC-UV Determination of Dextromethorphan in Syrup Method validation
}

\author{
NICOLAE AVRAM ${ }^{1}$, SIMONA CODRUTA HEGHES ${ }^{2}$, LUCA-LIVIU RUS ${ }^{3 *}$, ANCA MARIA JUNCAN ${ }^{3}$, LUCIA MARIA RUS ${ }^{2}$, \\ LORENA FILIP4, CORINA ROMAN FILIP5,6 \\ ${ }^{1}$ S.C. Bioef S.R.L., Independent Drug Analysis Laboratory, 1 Ferma Str., Dostat, 517275, Alba, Romania \\ ${ }^{2}$ Iuliu Hatieganu University of Medicine and Pharmacy, Department of Drug Analysis, 6 Louis Pasteur Str., 400349, Cluj-Napoca, \\ Romania \\ ${ }^{3}$ Lucian Blaga University, Faculty of Medicine, Preclinical Department, 2 A Lucian Blaga Str., 550169, Sibiu, Romania \\ ${ }^{4}$ Iuliu Hatieganu University of Medicine and Pharmacy, Department of Bromatology, Hygiene, Nutrition, 8 Victor Babes Str., \\ 400012, Cluj-Napoca, Romania \\ ${ }^{5}$ Lucian Blaga University, Faculty of Medicine, Clinical Department, 2 A Lucian Blaga Str., 550169, Sibiu, Romania \\ ${ }^{6}$ Academic Emergency Hospital Sibiu, Department of Neurology, 2-4 Pompeiu Onofreiu Str., 550166, Sibiu, Romania
}

\begin{abstract}
A HPLC-UV method, for determination of dextromethorphan hydrobromide in syrup, was validated. The chromatographic analysis was performed using an RP-18, Nucleodur chromatographic column $(250 \mathrm{~mm} x$ $4 \mathrm{~mm}, 5 \mu \mathrm{m})$ at constant temperature $\left(50^{\circ} \mathrm{C}\right)$ with a mobile phase consisting of a mixture of acetonitrile/ methanol ( 70:30 v/v) with sodium docusate (as ion pair agent) and ammonium nitrate, $\mathrm{pH}=3.4$. The flow rate of the mobile phase was $1 \mathrm{~mL} / \mathrm{min}$ and the detection was carried out at $280 \mathrm{~nm}$. System suitability, specificity, linearity, precision, accuracy, limit of detection and limit of quantification agreed with current pharmacopeial requests. The method is suitable for routine analysis of dextromethorphan hydrobromide in syrup.
\end{abstract}

Keywords: dextromethorphan, HPLC, validation, syrup

Dextromethorphan hydrodromide (DXHB) has been used as antitussive for more than half a century [1], single or in combinations [2]. DXHB is a non-selective serotonin uptake inhibitor and an agonist of sigma-1 receptor, and acts centrally to elevate threshold for coughing $[3,4]$. The activity of DXHB on N-methyl-D-aspartate receptor might have a contribution on antitussive effect, al so for cought in palliative care $[5,6]$.

Many papers describing DXHB analysis in pharmaceuticals (single or in combinations) and biological matrices, have been published: LC-MS [7], GC-MS $[8,9]$, cyclic voltammetry [10], capillary electrophoresis [11, 12], potentiometric [13, 14], spectrophotometric [14-17], LCUV [18-25]. This paper describes the development and validation of an HPLC-UV method for the determination of DXHB in syrup, considering latest validation guidelines and protocols [26-33].

\section{Experimental part}

\section{Materials and methods}

Standards, reagents and pharmaceutical substances

Glycerol (batch 1555415) and pharmaceutical sugar (batch 7161T43034) were supplied by AAK Sweden AB, Sweden and Tereos, France, respectively. DXBH, batch 4, was supplied by EDQM.

All reagents were analytical or HPLC grade: dioctyl sulfosuccinate sodium salt, batch A0258923 (Acros Organics, Belgium), glacial acetic acid, batch IL020161143) (International Laboratory, USA), ammonium nitrate, batch 060442300 (Chimopar, Romania), acetonitrile, batch 01507820 (Titolchimica SRL, Italy). All experiments were performed using ultrapure water.

\section{Apparatus and chromatographic conditions}

Ultrapure water was prepared by means of a Simplicity apparatus (Millipore), weighing was performed on a Mettler Toledo analytical balance, density $\left(\rho_{s}\right)$ was determined by means of KEM digital densimeter, chromatographic analysis was performed on an Rigol L-3000, HPLC system (quaternary pump, autosampler, column oven, DAD detector, Clarity chromatographic software). Samples were injected into an RP-18, Nucleodur chromatographic column ( $250 \mathrm{~mm} \times 4 \mathrm{~mm}, 5 \mu \mathrm{m})$ at constant temperature $\left(50^{\circ} \mathrm{C}\right)$. The mobile phase was prepared by solving $3.11 \mathrm{~g}$ of sodium docusate in a mixture consisting of $700 \mathrm{~mL}$ of acetonitrile and $300 \mathrm{~mL}$ of purified water, followed by the addition of $0.56 \mathrm{~g}$ of ammonium nitrate. The apparent $\mathrm{pH}$ was adjusted to 3.4 with glacial acetic acid. Injection volume was $20 \mu \mathrm{L}$, flowrate was $1 \mathrm{~mL} / \mathrm{min}$., detection wavelength was $280 \mathrm{~nm}$.

\section{Results and discussions}

Synthetic mixtures of the drug product components, preparation and sample preparation

In order to perform the validation of the method several synthetic mixtures of the drug product components (SMDPC), according to Annex 4 of the Marketing Authorization (MA) for the commercial product Tussin 6.5 $\mathrm{mg} / 5 \mathrm{~mL}$, syrup, considering different concentration levels of DXBH (0\% - 80\%-90\%-100\%-110\%-120\%) as stated in table 1.

An appropriate amount $(\approx 10 \mathrm{~g})$ of SMDPC, all series, except serie 7, was weighed in $100 \mathrm{~mL}$ volumetric flasks. All flasks were filled to mark with purified water and sonicated for 5 minutes and a filtration through acrodisc filters was performed prior to injection. For all series, except serie 7 , the relative density was determined.

\section{Method validation}

HPLC-UV method was validated in terms of system suitability, specificity, linearity, precision, accuracy, limit of detection (LOD), limit of quantification (LOQ).

System suitability was assessed considering the following acceptance criteria: peak repeatability (area RSD 
Table 1

SYNTHETIC MIXTURES OF THE DRUG PRODUCT COMPONENTS

\begin{tabular}{|c|c|c|c|c|c|c|c|c|c|c|}
\hline SMDPC Volume (mL) & \multicolumn{10}{|c|}{$50 \mathrm{~mL}$} \\
\hline Concentration level & $0 \%$ & $80 \%$ & $90 \%$ & $100 \%$ & $110 \%$ & $120 \%$ & $100 \%$ & $100 \%$ & $100 \%$ & Standard \\
\hline Number of Serie & 1 & 2 & 3 & 4 & 5 & 6 & 8 & 9 & 10 & 7 \\
\hline DXHB (mg) & 0 & 52.13 & 58.48 & 65.21 & 71.48 & 78.17 & 64.11 & 64.07 & 65.04 & 5.05 \\
\hline Sugar (mg) & \multicolumn{9}{|c|}{ According to Annex 4 of MA for Tussin $6.5 \mathrm{mg} / 5 \mathrm{~mL}$} & 0 \\
\hline Glycerol (mg) & \multicolumn{9}{|c|}{ According to Annex 4 of MA for Tussin $6.5 \mathrm{mg} / 5 \mathrm{~mL}$} & 0 \\
\hline Purified water (up to) & \multicolumn{10}{|c|}{$50 \mathrm{~mL}$} \\
\hline
\end{tabular}

\begin{tabular}{|c|c|c|c|c|c|}
\hline Serie & 2 & 3 & 4 & 5 & 6 \\
\hline$F_{\text {calculatod }}$ & 0.5154 & 0.2894 & 0.5154 & 0.4228 & 1.7366 \\
\hline$F_{\text {treorstical }}$ & \multicolumn{5}{|c|}{6.3882} \\
\hline $\mathrm{t}_{\text {calculatsod }}$ & 1.5368 & 1.4720 & 1.3837 & 1.2225 & 1.7289 \\
\hline$t_{\text {thessotical }}$ & \multicolumn{5}{|c|}{2.3060} \\
\hline
\end{tabular}

Table 2

STATISTICAL DATA FOR SPECIFICITY

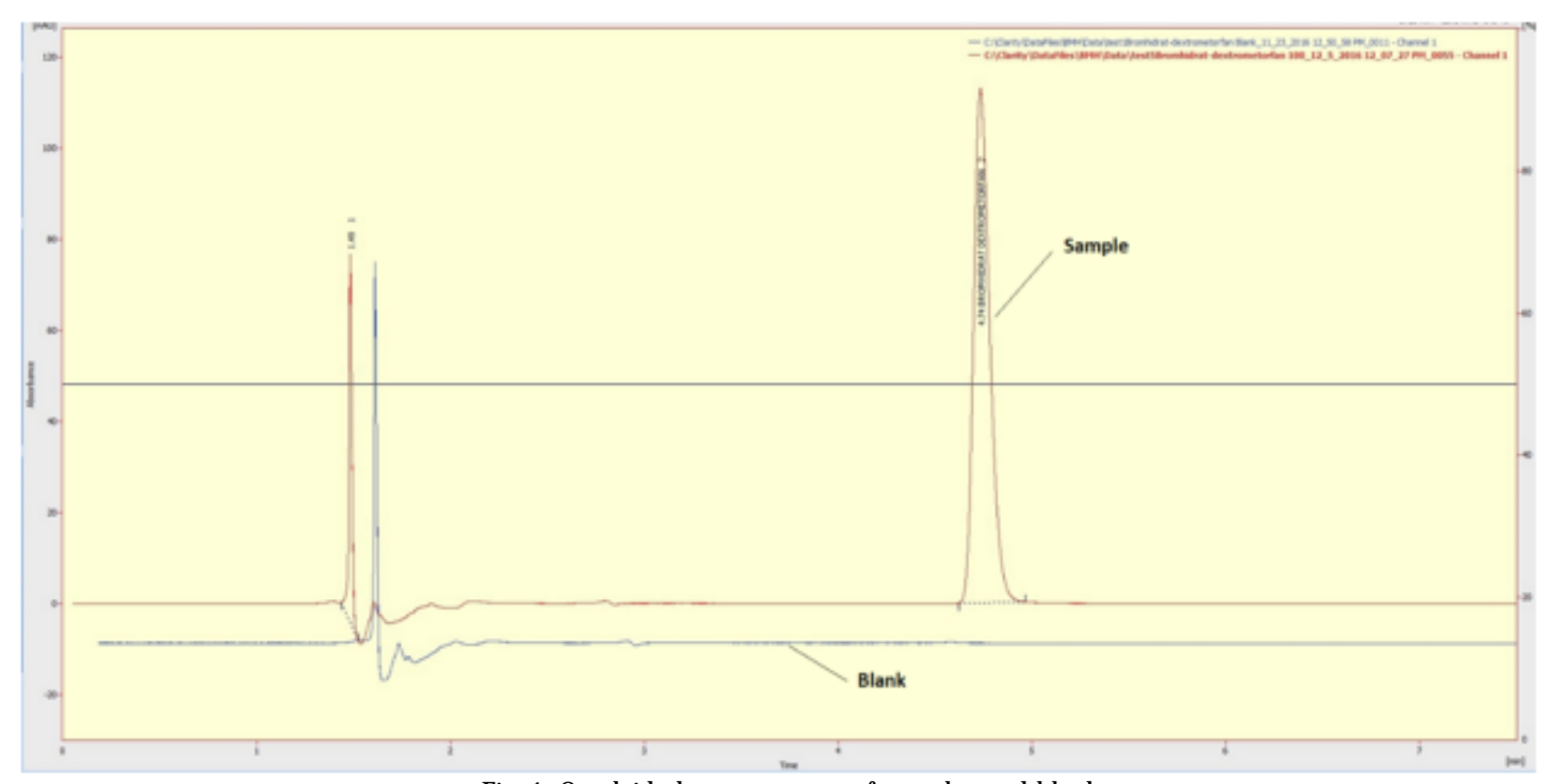

Fig. 1. Overlaid chromatograms of samples and blank

for 5 injections, serie 7) < 0.73\%, asymmetry 0.8-1.6, column efficacy (theoretical plates $-\mathrm{N}$ ) $>2000$. Area RSD for 5 injections was $0.615 \%$, asymmetry ranged 1.422 and 1.439 and $\mathrm{N}>15480$. All system suitability criteria were fulfilled.

Specificity was verified by performing 7 determinations (5 injection/determination) for series 1, 2, 3, 4, 5, 6 and 7. DXBH retention times of series 2, 3, 4, 5, and 6 were statistically compared with those related to serie 7 , by means of t-Student and Cohrane tests. Result are presented in table 2. Overlaid chromatograms of series 1, 2, 3, 4, 5 and 6 are showed in figure 1 . Retention time for DXHB was about $4.7 \mathrm{~min}$.

The information presented in table 2 and figure 1, leds us to the conclusion that serie 1 showed no analytical signal, $\mathrm{F}_{\text {calculated }}<\mathrm{F}_{\text {theoretical }}$ (the results are reproducible), $t_{\text {calculated }}<$ calculated $t_{\text {theoretical }}$ (theoretical means do not differ, statistically speaking), so developed method is specific.
Linearity was tested at 5 concentration levels (series 2, $3,4,5$ and 6), 5 replicates for each level. Acceptance criteria is correlation coefficient $(r)>0,99$. The results, related to linearity, are presented in table 3.

The calibration curve parameters were calculated in Microsoft Excel, and the calibration curve is presented in equation (1) and $r=0.9997$.

$$
A=7169.7 \times C_{s}-43.046
$$

The method proved to be linear in the range 0.0776 $0.1163 \mathrm{mg} / \mathrm{mL}$.

Precision of the method was proved by evaluating repeatability and reproducibility in three different days considering $100 \%$ concentration level (Series 8,9 and 10 ), 5 replicates each day. Statistical analysis of precision consisted off: variances homogeneity evaluation (Cochrane test), repeatability variation coefficient (CV\%) and reproducibility variation coefficient $\left(\mathrm{CV}_{\mathrm{B}} \%\right)$, considering a $5 \%$ error probability and $15(5 \times 3)$ samples. 
Table 3

LINEARITY RESULTS

\begin{tabular}{|c|c|c|c|c|c|c|c|}
\hline Sample & Sample mass (g) & $\begin{array}{l}\text { Sample density } \\
(\mathrm{g} / \mathrm{mL})-\rho_{\mathrm{s}}\end{array}$ & $\begin{array}{l}\text { Concentration of } \\
\text { injected solution } \\
(\mathrm{mg} / \mathrm{ml})-\mathrm{C}_{\mathrm{s}}\end{array}$ & $\begin{array}{l}\text { Theoretical } \\
\text { concentration in } \\
\text { SMDPC }(\mathrm{mg} / 5 \mathrm{~mL})\end{array}$ & $\begin{array}{c}\text { Mean area } \\
\text { - A }\end{array}$ & $\begin{array}{l}\text { Determined } \\
\text { concentration } \\
\text { in SMDPC } \\
(\mathrm{mg} / 5 \mathrm{~mL})\end{array}$ & $\begin{array}{c}\text { Recovery } \\
(\%)\end{array}$ \\
\hline Serie 2 & 10.0187 & 1.346 & 0.0776 & 5.213 & 518.517 & 5.2625 & 100.9501 \\
\hline Serie 3 & 10.0128 & 1.346 & 0.0870 & 5.848 & 583.073 & 5.8723 & 100.4156 \\
\hline Serie 4 & 10.0346 & 1.346 & 0.0972 & 6.521 & 640.628 & 6.3991 & 98.13116 \\
\hline Serie 5 & 10.0196 & 1.347 & 0.1063 & 7.148 & 715.799 & 7.1181 & 99.5811 \\
\hline Serie 6 & 10.0230 & 1.347 & 0.1163 & 7.817 & 798.8 & 7.8952 & 100.9999 \\
\hline
\end{tabular}

\begin{tabular}{|c|c|c|}
\hline $\begin{array}{c}\text { Variances homogeneity } \\
\text { (Cochrane test) }\end{array}$ & $\begin{array}{c}\text { Repeatability variation coefficient } \\
\left(\mathrm{CV}_{\mathrm{r}} \%\right)\end{array}$ & $\begin{array}{c}\text { Reproducibility variation } \\
\text { coefficient } \\
\left(\mathrm{CV}_{\mathrm{R}} \%\right)\end{array}$ \\
\hline \multicolumn{3}{|c|}{ Calculated values } \\
\hline 0.448 & 0.233 & 1.221 \\
\hline \multicolumn{3}{|c|}{ Theoretical values } \\
\hline 0.707 & Acceptance criteria & - \\
\hline $\mathrm{C}_{\text {calcalstod }}<\mathrm{C}_{\text {thessotical }}$ & - & - \\
\hline
\end{tabular}

Table 4

STATISTICAL EVALUATION OF PRECISION
Both variation coefficients should be below $2 \%$. Statistical evaluation of precision is presented in table 4.

As stated in table 4, all variances are homogeneous (since $\mathrm{C}_{\text {ald }}<\mathrm{C}_{\text {thereitial }}$ ), and both variation coefficients are below $2 \%$. The method is precise.

Accuracy of the method was estimated by means of recovery using the same samples described in linearity testing (series 2, 3, 4, 5 and 6) in triplicate.
Statistical analysis of accuracy was performed by: Cochrane test (intragroup variance evaluation), Fisher test (mean recovery validity), tStudent test (confidence interval for mean recovery). Statistical evaluation of accuracy is presented in table 5.

As shown in table 5, all variances are homogeneous $\left(\mathrm{C}_{\text {calculated }}<\mathrm{C}_{\text {theoretica }}\right)$, mean recoveries are valid ( $\mathrm{F}_{\text {calculated }}<$ $F_{\text {theoretical }}$ and confidence interval is very close to $100 \%$. The method is accurate.

\begin{tabular}{|c|c|c|}
\hline $\begin{array}{c}\text { Intragrup variance } \\
\text { homogeneity } \\
\text { (Cochrane test) }\end{array}$ & $\begin{array}{c}\text { Medium recovery validity } \\
\text { (Fischer test) }\end{array}$ & $\begin{array}{c}\text { Confidence interval of the } \\
\text { mean recovery (\%) }\end{array}$ \\
\hline \multicolumn{3}{|c|}{ Calculated values } \\
\hline 0.396 & 0.036 & $99.499-100.784$ \\
\hline 0.68 & Theoretical values & \\
\hline \multicolumn{3}{|c|}{3.48} \\
\hline
\end{tabular}

Table 5

STATISTICAL EVALUATION OF ACCURACY 


\begin{tabular}{|c|c|c|}
\hline Calibration curve slope & \multicolumn{2}{|c|}{7169.7} \\
\hline Standard deviation of blank & $\mathrm{mg} / \mathrm{mL}$ & $\mu \mathrm{gg} / \mathrm{mL}$ \\
\hline & & $4.142 \times 10^{-3}$ \\
\hline LOD & $4.142 \times 10^{-6}$ & $1.38 \times 10^{-2}$ \\
\hline LOQ & $1.38 \times 10^{-5}$ & \\
\hline
\end{tabular}

Table 6

LOD AND LOQ
Limit of detection (LOD) and limit of quantification (LOQ) were determined based on signal-to-noise approach and are presented in table 6.

\section{Conclusions}

A HPLC-UV method, for determination of dextromethorphan hydrobromide in syrup, was validated in terms of system suitability, specificity, linearity, precision, accuracy, limit of detection and limit of quantification. All system suitability criteria were fullfilled. The method is: specific (results are reproducible and the means do not differ, statistically speaking), linear (over the concentration range $0.0776-0.1163 \mathrm{mg} / \mathrm{mL}$, correlation coefficient $r=$ 0.9997), precise (all variances are homogeneous and both repeatability and reproducibility coefficients are below $2 \%$ ), accurate (variances are homogeneous, mean recoveries are valid, and confidence interval is very close to $100 \%$ ). LOD and LOQ are $4.142 \times 10^{-3} \mu \mathrm{g} / \mathrm{mL}$ and $1.38 \times 10^{-2} \mu \mathrm{g} /$ $\mathrm{mL}$, respectively. The HPLC-UV is suitable for routine quantitative determination of dextromethorphan hydrobromide in syrup.

\section{References}

1. TAYLOR, C.P., TRAYNELIS S.F., SIFFERT, J., POPE L.E., MATSUMOTO R.R., Pharmacol. Ther., 164, 2016, p. 170.

2. CRISTEA, A.N., Tratat de Farmacologie, 1, Editura Medicala, Bucuresti, 2006, p. 355-358.

3. RANG, H.P., RITTER, J.M., FLOWER, R.J ., HENDERSON G., Rang \& Dale's Pharmacology, 8, Elsevier Churchill Livingstone, 2016, p. 353, 520.

4. BRUNTON, L., CHABNER, B., KNOLLMAN, B., Goodman \& Gilman's The Pharmacological Basis of Therapeutics, McGraw Hill Medical, 12, BRUNTON, L., 2011, p. 513.

5. RAYNOLDS, S.M., MACKENZIE A.J., SPINA, D., PAGE, C.P., Trends Pharmacol. Sci., 25, 11, 2004, p. 569.

6. MORICE, A.H., SHANKS, G., Curr. Opin. Support. Palliat. Care, 11, 3, 2017, p. 147.

7. THURMAN, E.M., FERRER I., J. Chromatogr. A, 1259, 2012, p. 158. 8. KIM, E. M., LEE, J. S., PARK M. J., CHOI, S. K., LIM, M.A., CHUNG, H.S., Forensic Sci. Int., 161, 2006, p. 198.

9. SPANAKIS, M.,VIZIRIANAKIS, I.S., TZOUVELEKI, M.M., NIOPAS, I., Biomed. Chromatogr., 23, 2009, p. 1131.

10. HELI, H., MAJDI, S., JABBARI, A., SATTARAHMADY, N., MOOSAVIMOVAHEDI, A.A., J. Solid State Electrochem, 14, 2010, p. 1515.

11. GOMEZ, M.R., OLSINA R.A., MARTINEZ, L.D., SILVA, M.F., J. Pharm. Biomed. Anal., 30, 2002, p. 791.
12. DONG, Y., CHEN, X., CHEN, Y., CHEN, X., HU, Z., J. Pharm. Biomed. Anal., 39, 2005, p. 285.

13. KHALED, E., HASSAN, H.N.A., MOHAMED G.G., SELEIM, A.A., Talanta, 81, 2010, p. 510.

14. ELMOSALLAMY, M.A.F., AMIN, A.S., Anal. Sci., 30, 2014, p. 419.

15. MURTHA, J.L., JULIAN, T.N., RADEBAUGH, G.W., J. Pharm. Sci., 77, 8, 1988, p. 715.

16. LEE, A.R., HU, T.M., J. Pharm. Biomed. Anal., 12, 6, 1994, p. 747. 17. KOMPANY-ZAREH, M., MIRZAEI, S., Anal. Chim. Acta, 526, 2004, p. 83.

18. McSHARRY, W.O., SAVAGE, I.V.E., J. Pharm. Sci., 69, 2, 1980, p. 212. 19. CHEN, T.M., PACIFICO, J.R., DALY, R.E., J. Chromatogr. Sci., 26, 1988, p. 636.

20. WILSON, T.D., JUMP, W.G., NEUMANN, W.C., SAN MARTIN, T., J. Chromatogr., 641, 1993, p. 241.

21. THUAUD, N., GOSSELET, N.-M., SEBILLE, B., J. Incl. Phenom. Mol. Recognit. Chem., 25, 1996, p. 267.

22. GALLI, V., BARBAS, C., J. Chromatogr. A, 1048, 2004, p. 207.

23. ALI, M.S., GHORI, M., RAFIUDDIN, S., KHATRY, A.R., J. Pharm. Biomed. Anal., 43, 1, 2007, p. 158.

24. LOUHAICHI, M.R., JEBALI, S., LOUESLATI, M.H., ADHOUM, N., MONSER, L., Talanta, 78, 3, 2009, p. 991.

25. MOEIN, M.M., JAVANBAKHT, M., AKBARI-ADERGANI, B., J. Chrom. B, 879, 11-12, 2011, p. 777.

26. $* * * \mathrm{ICH}$ Harmonised Tripartite Guideline, Validation of analytical procedures: text and methodology Q2(R1). Step 5: Note for guidance on validation of analytical procedures: text and methodology (CPMP) ICH/381/95), 2006.

27. BLIESNER, D., Validating Chromatographic Methods A Practical Guide, J ohn Wiley \& Sons, New J ersey, 2006, p. 170-217.

28. TEASDALE, A., ELDER, D., NIMS, R.W., ICH Quality Guidelines An implementation Guide, John Wiley \& Sons, Hoboken, 2017, p. 127166.

29. VIERU, M., BIBIRE, N., PESTE, G., DORNEANU, V., POTORAC, L., Rev. Chim. (Bucharest), 64, no. 3, 2013, p. 298.

30. MAHU, S.C., SPAC, A. F., CIOBANU, C., HANCIANU, M., AGOROAIEI, L., BUTNARU, E., Rev. Chim. (Bucharest), 67, no. 3, 2016, p. 414. 31. SPAC, A.F., GRIGORIU, I.C., CIOBANU, C., AGOROAIEI, L., STRUGARU, A.M., BUTNARU, E., Rev. Chim. (Bucharest), 67, no. 6, 2016, p. 1227.

32. IUGA, C., MOLDOVAN, M., POPA, A., LEUCUA, S. E., Farmacia, 56, 3, 2008, p. 254.

33. HEGHES, S. C., RUS, L. M., RUS, L. L., BOJITA, M. T., IUGA, C. A., Farmacia, 65, 5, 2017, p. 755.

$\overline{\text { Manuscript received: } 5.02 .2018}$ 